\title{
Recycled waste paper-cement composite panels reinforced with kenaf fibres: durability and mechanical properties
}

\author{
Stephen Osakue Amiandamhen ${ }^{1,3} \cdot$ Samson Omokaro Osadolor ${ }^{2,3}$
}

Received: 4 September 2019 / Accepted: 10 April 2020 / Published online: 24 April 2020

(c) The Author(s) 2020

\begin{abstract}
There is a growing interest on recycling of waste fibres as an alternative to landfill disposal. The aim of the study was to investigate the durability and mechanical properties of waste paper-cement composite panels reinforced with varying kenaf fibre content (FC, 2-10\%). The panels produced were evaluated for properties including modulus of rupture (MOR) and apparent modulus of elasticity (MOE). The resistance of the panels was tested in the field for both termite damage and fungi decay for a period of 24 weeks. Accelerated decay test was also performed on selected samples. The results showed that the mean MOR ranged from 3.17 MPa for samples with 10\% FC to $4.84 \mathrm{MPa}$ for samples with $8 \% \mathrm{FC}$. The mean MOE ranged from $248 \mathrm{MPa}$ for samples with 10\% FC to $1298.1 \mathrm{MPa}$ for samples with $8 \%$ FC. Statistical analysis showed that the effect of the fibre content was significant on the properties evaluated $(p<0.05)$. The study concluded that the optimum fibre content for improving the strength and physical properties of paper-cement composites in a ratio of $1: 1(\mathrm{w} / \mathrm{w})$ using kenaf as reinforcing fibre is $8 \%$. The panels were highly resistant to both termite and fungi attack for the study duration.
\end{abstract}

Keywords Durability $\cdot$ Fungi $\cdot$ Kenaf bast fibres $\cdot$ Termite $\cdot$ Waste paper-cement composites

\section{Introduction}

Fibre-reinforced cement composites, as a building material, is not a novel subject. In prehistoric times, natural fibres were used to reinforce clay bricks, and since mid to late twentieth century, different materials made from natural fibres and cementitious materials have been produced. Natural fibres are regarded as important alternative to synthetic fibres such as asbestos, glass, carbon and aramid [1]. Since the last decades, composite boards produced with asbestos fibres have been replaced due to the health hazards associated with such fibres. In a world driven by change, researchers are taking considerable efforts to develop building panels that are cost-effective and environment friendly. One of the

Stephen Osakue Amiandamhen

stephen.amiandamhen@lnu.se

1 Department of Forestry and Wood Technology, Linnaeus University, 35195 Växjö, Sweden

2 Department of Innovation in Biological, Agro-Food and Forest Systems, University of Tuscia, 01100 Viterbo, Italy

3 Department of Forest Resources and Wildlife Management, University of Benin, Benin City 1154, Nigeria main drivers is to find new ways of utilizing natural fibres for composite production, which in turn could increase the applicability of bio-based panels. Natural fibres from different plants including bagasse, rice husk, kenaf and coir have been studied in bio-based composites [2-4]. Similarly, the potentials of pulp fibres and paper sludge in cement composites have been studied [5, 6], and is still the subject of many studies directed toward beneficial uses of waste paper fibres.

Paper production and recycling generate substantial amount of waste fibres, which can be utilized in valueadded manufacturing. During paper recycling, the length and strength of fibres decrease due to degradation, thereby making recycled fibres unsuitable as raw materials for papermaking [7]. Alternatively, the recycled fibres can be used in the production of activated carbon, which is useful in environmental protection and water purification [7]. Waste fibres have been used to reinforce plastics, cement and other hydrophobic polymers, and there has been an increased effort towards promoting a circular bioeconomy by recycling these materials in new composite products $[8$, 9]. The use of waste fibre-reinforced composites in housing construction will not only alleviate the pressures of overexploitation of plant-based fibres, but also serve as avenues 
for the utilization of abundant waste fibres generated in paper recycling mills [10].

Natural fibre composites will continue to gain industrial interest due to their design flexibility and structural applications [11], as well as biological and environmental durability [12]. The incorporation of natural fibres in cement matrix will continue for a long time because the fibres are renewable, affordable, elastic and have low production energy, making them good materials for the reinforcement of cementbased composites [13, 14]. Natural fibres in cement matrix influence most of the mechanical properties of the composites, but may pose a serious drawback due to degradation in alkaline cement. Occasionally, fibres inhibit the setting of cement and invariably affect the properties of the composites [15]. This limitation is due to the natural incompatibility between hydrophilic biomaterial and hydrophobic cement. Another drawback of natural fibres in cement is the presence of hydroxyl groups on the surface of fibres, which affects the dimensional stability of the composites. These limitations can be carefully controlled, and many treatment methods have been extensively reviewed [2, 16-19]. It was concluded that the modification of fibres results in improved surface properties and reduced hydroxyl groups, thereby enhancing the properties of the composite material. Similarly, the use of cement setting accelerators, which reduces the hydration time of cement has been reported to yield good results $[2$, $15,20]$.

Generally, fibre cement composites are resistant to rot and termite attack [21, 22]. However, with prolonged exposure to environmental factors, the durability of the materials is of important consideration [23]. The fibres may absorb water and swell, and then rotting occurs by fungal attack $[24,25]$. Similarly, termites may attack cellulose and other components in weathered wood based cement composites $[22,26]$. These attacks may cause discolouration, reduction in strength and structural failure. Many of the studies on the effects of fungi and termites on natural fibre composites were conducted in laboratory conditions, which sometimes may not predict the actual performance of the materials in the field. Secondly, the selected strains of fungal and termite species for laboratory studies may not even be present in the field, and where applicable, potency may be affected in lab conditions. Azrieda et al. [27] reported that the most acceptable scientific study in evaluating the durability of wood-based materials is by the graveyard test, where the materials are partially buried and durability rating is measured by the length of time the material remains unaffected. Therefore, an on-site assessment of the potential effects of these biotic factors is important to evaluate the durability of composite materials that are targeted for field applications. There are very few literature on weathering performances of waste paper composites, and none of the studies investigated biological attacks on waste paper-cement composites. This study evaluates the effect of fungi and termite exposure on waste fibre composites. Therefore, the study is imperative to evaluate the properties and durability of paper-cement composites for use as outdoor wall claddings in a research arboretum.

The rationale for the study was to explore the high volume of waste paper in the manufacturing of value-added products, and to investigate the effect of vegetable fibre addition on the durability of recycled paper-cement composites. Kenaf bast fibres (Hisbiscus cannabinus) were selected to be used as reinforcement in the paper-cement composites. The basis for this selection was due to the results obtained when kenaf fibres were used to reinforce cement matrix in previous study [2]. This study seeks to determine the optimum amount of kenaf fibre that yields the best mechanical performance in the composites. A cement setting accelerator was used to reduce the effect of the fibres in the matrix as observed by Amiandamhen et al. [2]. Since the panels will be used in the field as non-load-bearing structures, it is important to evaluate some properties of the panels, which are likely to be affected by prolonged weather exposure. In addition, the presence of natural fibres and waste paper in the cement matrix poses a structural concern with longterm durability. This study thereby evaluates the flexural and physical properties, as well as the termite damage and fungal decay resistance of the composite panels.

\section{Materials and methods}

The kenaf bast fibres (Fig. 1) used in this research were obtained from the Institute of Agricultural Research and Training (IAR\&T), Moor Plantation, Ibadan. The waste papers were sourced locally from a recycling mill, while the Portland cement (Type I) was purchased for the study. The waste papers were soaked in water for about $48 \mathrm{~h}$. The wet papers were shredded and sun dried for about $6 \mathrm{~h}$. Thereafter, the papers were pulverized into sizes of $2-3 \mathrm{~mm}$, and air-dried for $24 \mathrm{~h}$. The dried pulverized papers were mixed with cement based on the design proportions. Kenaf fibres and water containing dissolved calcium chloride salt $\left(\mathrm{CaCl}_{2}\right)$ were also weighed and added to the mix. $3 \% \mathrm{CaCl}_{2}$, based on the weight of cement, was dissolved in $432.36 \mathrm{ml}$ of water and used as cement setting accelerator. The amount of water added to the mix was adapted from previous studies [2]. The ratio of cement and wastepaper was kept constant $(1: 1 \mathrm{w} / \mathrm{w})$ for all composite boards produced. The selected ratio was based on the results from preliminary experimental design, and it was aimed at utilizing as much paper materials as technically feasible. The kenaf fibre content was varied from $2,4,6,8$ and $10 \%$ in the paper-cement composite. These percentages were based on the dry weight of the board (see Table 1). The fibres were cut into sizes of $3-5 \mathrm{~cm}$. This was 
Fig. 1 Kenaf bast fibres: a whole length fibres, $\mathbf{b}$ cut and treated fibres
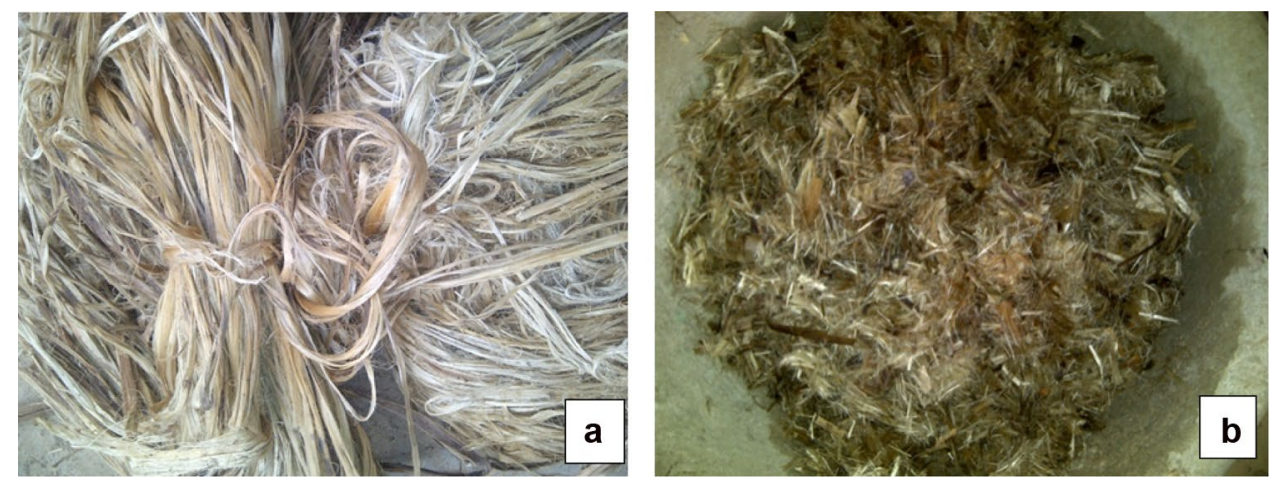

Table 1 Mean values and multiple range test for mechanical properties of the composite samples

\begin{tabular}{llclr}
\hline Fibre content $(\%)$ & Fibre mass $(\mathrm{g})$ & MOE $(\mathrm{MPa})$ & MOR $(\mathrm{MPa})$ & \multicolumn{1}{c}{ IB $(\mathrm{MPa})$} \\
\hline Control & Control & $621.1^{\mathrm{ab}} \pm 489.0$ & $3.88 \pm 1.94$ & $0.021^{\mathrm{c}} \pm 0.04$ \\
2 & 441 & $549.8^{\mathrm{ab}} \pm 85.61$ & $3.40 \pm 0.07$ & $0.071^{\mathrm{b}} \pm 0.01$ \\
4 & 220.5 & $429.1^{\mathrm{b}} \pm 150.44$ & $3.29 \pm 0.98$ & $0.082^{\mathrm{b}} \pm 0.01$ \\
6 & 147 & $671.1^{\mathrm{ab}} \pm 890.02$ & $3.79 \pm 0.11$ & $0.084^{\mathrm{b}} \pm 0.02$ \\
8 & 110.3 & $1298.1^{\mathrm{a}} \pm 5.12$ & $4.84 \pm 0.81$ & $0.12^{\mathrm{a}} \pm 0.05$ \\
10 & 88.2 & $248.0^{\mathrm{b}} \pm 392.49$ & $3.17 \pm 1.43$ & $0.02^{\mathrm{c}} \pm 0.03$ \\
\hline
\end{tabular}

Each value represents mean data of three replicates with standard deviation

Means in the same column with the same superscript are not significantly different $(p<0.05)$ done to avoid balling problems during mixing and to facilitate homogenous mixing of the materials [2]. The materials were mixed in a mechanical mixer. The slurry produced was poured in a wooden mould measuring $350 \mathrm{~mm}$ (length) $\times$ $350 \mathrm{~mm}$ (width) and pre-pressed. The wet board formed was then pressed at a pressure of 1.23 MPa to a final thickness of $6 \mathrm{~mm}$ using the hydraulic press. After $24 \mathrm{~h}$, the boards were demoulded and cured for 28 days in ambient conditions. The target board density was $1.2 \mathrm{~g} / \mathrm{cm}^{3}$.

\section{Board tests}

The boards were trimmed to avoid edge effects and were cut into test sample sizes of $150 \times 50 \times 6 \mathrm{~mm}$ according to the ASTM standard [28]. The samples were conditioned at $20{ }^{\circ} \mathrm{C}$ and $65 \%$ relative humidity (RH) for $96 \mathrm{~h}$ before testing. The boards were tested for mechanical properties, dimensional stability as well as termite and fungi resistance. The mechanical properties evaluated were modulus of rupture (MOR), apparent modulus of elasticity (MOE) and internal bond strength (IB). Three samples were randomly selected from the boards for different fibre contents. Three-point flexural test was carried out using a universal testing machine at cross head speed of $5 \mathrm{~mm} / \mathrm{min}$. MOR and MOE were derived from the flexural test as described in ASTM [28]. IB was conducted using $50 \times 50 \mathrm{~mm}$ square samples glued to aluminium blocks and tested according to the ASTM procedure [28]. The physical properties evaluated include water absorption (WA), thickness swelling (TS) and linear expansion (LE). Samples were tested for dimensional stability after $24 \mathrm{~h}$ water submersion. Three test samples measuring $50 \times 50 \mathrm{~mm}$ were randomly selected from the boards for each test. Increase in weight and dimensions of the samples after $24 \mathrm{~h}$ submersion was calculated based on the relationship in ASTM [28]. After outdoor exposure to fungi and termite damage, mechanical properties were tested to evaluate the possible effects of such exposure on the panel strength.

\section{Fungi decay and termite damage test}

Fungal decay test was carried out in the field, the so-called graveyard test. Samples were partially buried in decaying organic soil with reported fungal activity including the dematiaceous mould (Chaetomium globosum, Kunze ex Fr.). This saprophytic fungus primarily resides in soil and decaying humus. It causes soft rot and decomposes plant cells using hyphal cellulase activity, which performs best at high tropical temperatures [29]. The fungus also changes the colour of paper. Samples were observed for the presence of fungal hyphae or discoloration. This test was conducted since the samples consisted of papers and plant fibres, which are likely to be affected in the presence of moisture and soil nitrogen. The test was necessary because the composite materials will be used in application directly in ground contact at the location of the test site. The test samples were 
observed for a period of 24 weeks. Accelerated decay test was also conducted on the samples with the best mechanical property. Pure strains of the brown rot fungi (Coniophora puteana) and white rot fungi (Trametes versicolor) growing on malt agar were collected. Ten replications per fungal test and ten control samples measuring $25 \times 25 \mathrm{~mm}$ were used for the study. The samples were kept in a sterilized chamber prior to the decay tests. For the test, the samples were placed on sterile supports in a jar containing the fungi. Then they were incubated for 12 weeks at $20{ }^{\circ} \mathrm{C}$ and $80 \% \mathrm{RH}$. After incubation, the samples were removed, cleaned and conditioned to constant weight. The average weight loss was expressed as a percentage of the initial weight of the sample. The average weight loss was thereafter corrected using the weight loss of the control sample to give the average corrected weight loss. Termite damage test was carried out in the proximity of the arboretum, in an active termite mound. Termite mounds are characteristics features of African savanna and woodlands, and are important to the ecological processes [26, 30]. The genus Macrotermes are responsible for large-scale damage to residential buildings and farm structures [22]. They decompose plant materials indirectly by the action of a basidiomycete fungus [31]. Samples were inserted into the mound and were observed for termite damages including galleries. This test was assessed for a period of 24 weeks.

\section{Data analysis}

The experiment was arranged in a completely randomized design (CRD) with five treatment levels representing the fibre contents and a control, each with three replicates. Analysis of variance procedure was conducted to analyse the effect of the fibre contents on the mechanical properties of the boards. Duncan's multiple range test (DMRT) was used in the separation of means where significant differences occurred.

\section{Results and discussion}

\section{Effects of fibre content on mechanical properties}

The mean values of modulus of rupture (MOR), apparent modulus of elasticity (MOE) and internal bonding (IB) of the samples with different fibre contents are presented in Table 1. The samples with $8 \%$ fibre content had the highest strength property with values of $4.84,1298.1$ and $0.12 \mathrm{MPa}$ for MOR, MOE and IB, respectively. This was followed by samples with $6 \%$ fibre content for all measured strength properties. A similar trend in mean strength values was observed for both MOR and MOE. As the fibre content increased, the strength properties decreased slightly, and increased at $6 \%$ fibre content. The maximum strength property was achieved at $8 \%$ fibre content for all measured properties. Thereafter, addition of fibres above $8 \%$ caused a decrease in the strength properties of the samples. The high strength values of samples containing $8 \%$ fibre content was possibly due to good distribution of fibres within the matrix and good interfacial bonding in the composite material.

Samples with $10 \%$ fibre content had the lowest mean strength values of 248, 3.17 and $0.02 \mathrm{MPa}$ for MOE, MOR and IB, respectively. This was evident from the brittle nature of the samples prepared with $10 \%$ fibre addition. The low strength values at $10 \%$ fibre content could be due to poor distribution of fibres within the matrix, because of the difficulties that were encountered during mechanical mixing of the fibres, papers and matrix. The inadequate mixing resulted in poor uniformity in the composites, poor interfacial adhesion and ultimately low strength properties. Mohr et al. [32] reported an increase in all strength properties with increasing fibre content. However, compressive strength and toughness were adversely affected due to difficulties in compaction caused by increased fibre content [33] and degree of alignment of the fibre in the matrix [34]. Thus, with increased fibre content, proper alignment provides better results in strength properties. The mean IB values of the samples increased with increasing fibre contents, with the exception of samples made with $10 \%$ fibre content. However, the control sample and the sample containing $10 \%$ fibre content had the lowest mean IB value of $0.02 \mathrm{MPa}$. This could possibly be due to lack of fibre reinforcement in the control and in the poorly distributed samples. It can be stated therefore, from the result of this study, that the optimum fibre content required for improving the MOR, MOE and IB strength of paper-cement composite boards in a $1: 1(\mathrm{w} / \mathrm{w})$ ratio is $8 \%$. Coutts [35] also reported that the optimum fibre content in a fibre cement composite for improving the flexural strength and toughness was between the range of $8-12 \%$. Similarly, Oladele et al. [36] observed that the optimum fibre mass fraction for strengthening wastepaper-cement composite ratio of $1: 3$ using natural sponge fibre was $4 \%$. The analysis revealed that the effect of the fibre content was significant on the MOE and IB of the boards (Table 2).

Table 2 Analysis of variance procedure for mechanical properties of the samples

\begin{tabular}{llll}
\hline & MOR & MOE & IB \\
\hline$F$ value & 2.46 & 3.95 & 11.36 \\
$p$ value & 0.0940 & 0.0238 & 0.0003 \\
\hline
\end{tabular}




\section{Effects of fibre content on physical properties}

The mean values of water absorption (WA), thickness swelling (TS) and linear expansion (LS) of the samples after $24 \mathrm{~h}$ water submersion are presented in Table 3 . The control samples had the lowest WA with a mean value of $47.59 \%$. The high WA in samples with $10 \%$ fibre content was likely due to the high fibre content in the board. The boards produced with $10 \%$ fibre content also had the highest TS and LE with mean values of 20.37 and $7.71 \%$, respectively. As the amount of fibre in the composite increases, there is an increase in the polar hydrophilic group, which increases the WA of the material. As WA increases, TS and LS also increase. In addition, the poor fibre distribution and weak interfacial bonding, owing to the difficulty in mixing high proportion of fibre and paper-cement, resulted in porous composite boards. This inevitably affected the dimensional stability of the boards. Other studies also reported a similar relationship between high fibre content and dimensional stability in cementbonded composites [1, 2, 36, 37]. The samples with $6 \%$ fibre content had the lowest TS, while samples with $4 \%$ fibre content had the lowest LE of 9.39 and $5.11 \%$, respectively. Generally, all the samples absorbed more water after $24 \mathrm{~h}$ submersion than the minimum requirements for cement-bonded particleboard [38]. This was possibly due to the paper material, which was used in a 1:1 ratio with cement. The result of the analysis of variance showed that the fibre content had a significant effect on the WA and LE of the boards, $p<0.05$ (Table 4).

Table 3 Mean values and multiple range test for physical properties of the composite samples

\begin{tabular}{lcrr}
\hline Fibre content $(\%)$ & \multicolumn{1}{l}{ WA $(\%)$} & \multicolumn{1}{l}{ TS $(\%)$} & \multicolumn{1}{l}{ LE $(\%)$} \\
\hline Control & $47.59^{\mathrm{c}} \pm 2.91$ & $11.74 \pm 3.40$ & $5.61^{\mathrm{a}} \pm 0.99$ \\
2 & $57.57^{\mathrm{bc}} \pm 3.90$ & $9.74 \pm 3.63$ & $5.19^{\mathrm{ab}} \pm 3.10$ \\
4 & $58.36^{\mathrm{b}} \pm 10.80$ & $9.83 \pm 5.68$ & $5.11^{\mathrm{ab}} \pm 1.93$ \\
6 & $54.84^{\mathrm{bc}} \pm 3.64$ & $9.39 \pm 4.28$ & $5.95^{\mathrm{a}} \pm 1.85$ \\
8 & $51.99^{\mathrm{bc}} \pm 4.25$ & $9.93 \pm 4.48$ & $5.13^{\mathrm{ab}} \pm 0.41$ \\
10 & $76.10^{\mathrm{a}} \pm 1.85$ & $20.37 \pm 7.09$ & $7.71^{\mathrm{a}} \pm 0.64$ \\
\hline
\end{tabular}

Each value represents the mean data of three replicates with standard deviation

Means in the same column with the same superscript are not significantly different $(p<0.05)$

Table 4 Analysis of variance procedure for physical properties of the samples

\begin{tabular}{llll}
\hline & WA & TS & LE \\
\hline$F$ value & 9.91 & 2.08 & 3.56 \\
$p$ value & 0.0006 & 0.1381 & 0.0332 \\
\hline
\end{tabular}

\section{Durability properties}

The durability of the composite samples in the field was assessed for fungal decay and termite damage. This test was necessary to evaluate the long-term structural durability of the composites in outdoor applications. Visual examination revealed that the samples were highly resistant to fungal decay, since the partially buried samples showed no significant fungal activity after a 24 -week exposure period. However, small dark stains were observed on the surface of the samples, which were probably due to dark stain fungus (Fig. 2b). Accelerated decay test was also conducted on the samples with the best mechanical properties, i.e. samples with $8 \%$ fibre content. Examination after a 12-week exposure also revealed a strong resistance to both brown and white-rot fungi, with no visible fungal activities. Okino et al. [21] reported that cement-bonded particleboards, after a 12-week accelerated decay test, were resistant against the brown-rot fungus Gloeophyllum trabeum (Persoon ex Fries.) Murrill, and the white-rot fungus Trametes versicolor (Linnaeus: Fries) Pilát. However, there was a slight presence of mycelium observed on the surface of the composite boards [21]. In another study, Shirakawa et al. [24] found that certain group of fungi contributed to darkening of fibre cement boards, owing to their mode of attack and the brown to black colour of their hyphae or spores. Decay resistance of the selected samples was expressed based on their average weight loss after the incubation period (Table 5). The average weight loss was corrected using the weight loss of the control sample to give the actual weight loss caused by the fungal exposure. It was observed that samples exposed to white-rot fungus had some weight gain, probably due to natural carbonation of cement. All the tested samples showed high resistance to fungal attack, with very little changes in sample weights after incubation. Based on ASTM classification of wood decay resistance expressed as weight loss [39] (Table 6), all samples were classified as highly resistant. There are other classification systems, which are not applicable to this study. The natural durability of wood can be based on the average service life of test samples subjected to graveyard test [27]. Similarly, the durability of wood after 16 -week accelerated fungal decay test is classified within a five-grade scale using the $X$-value classifications according to EN 350-1 [40].

The tested samples were highly resistant to termite damage within a test duration of 24 weeks (Fig. 2d). This classification was based on the visual examination procedure reported by Garcia et al. [22]. According to this classification, termite damage was arbitrarily rated between 0 (no attack - highly resistant) and 100\% (severely attacked—not resistant). In their study, wood cement boards exposed in the field were highly resistant to termite damage over a period of 5 years [22]. Other studies reported varying resistance 
Fig. 2 Durability test: a graveyard test, $\mathbf{b}$ samples with fungi stains after graveyard test, c field termite damage test, $\mathbf{d}$ samples after termite damage test
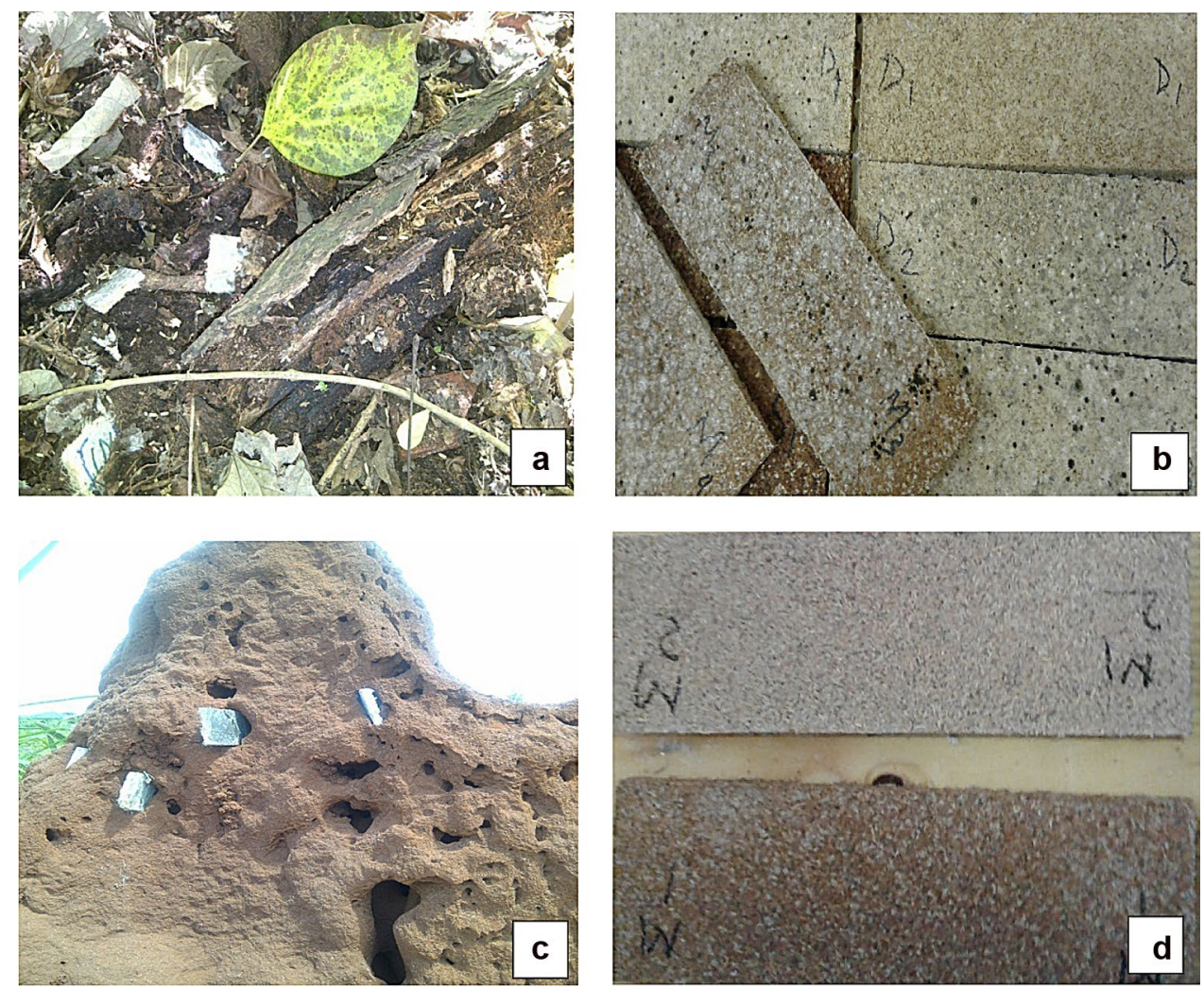

Table 5 Average weight loss of the samples after 12-week accelerated decay test and control samples

\begin{tabular}{lll}
\hline \multirow{2}{*}{ Samples } & \multicolumn{2}{l}{ Average weight loss (\%) } \\
\cline { 2 - 3 } \cline { 2 - 2 } Exposed samples & Brown-rot & White-rot \\
\hline Control samples & $1.47(1.76)$ & $-1.21(1.03)$ \\
\hline
\end{tabular}

Each value represents the mean data of 10 replicates with standard deviation in parenthesis

Table 6 Class of wood decay resistance expressed as either weight loss or residual weight [39]

\begin{tabular}{lll}
\hline $\begin{array}{l}\text { Average weight loss } \\
(\%)\end{array}$ & $\begin{array}{l}\text { Average residual } \\
\text { weight }(\%)\end{array}$ & Class resistance \\
\hline $0-10$ & $90-100$ & Highly resistant \\
$11-24$ & $76-89$ & $\begin{array}{l}\text { Resistant } \\
25-44\end{array}$ \\
45 or above & $56-75$ & $\begin{array}{l}\text { Moderately resistant } \\
\end{array}$ \\
\hline
\end{tabular}

to subterranean termites, both in laboratory conditions and actual field exposure. It was reported that the overall resistance of cement boards to damage depends on the natural durability of the materials, fibre modification if any, and the type of cement used [22, 41, 42]. The high resistance observed in this study could be attributed to the composite materials such as calcium chloride $\left(\mathrm{CaCl}_{2}\right)$ and silica $\left(\mathrm{SiO}_{2}\right)$, which are intolerant to termites and fungi. In addition, the alkalinity of cement matrix inhibits the deterioration of fibre cement products by fungi and termite [21, 43]. It can be argued that the durability of the cement composites in this study is not a function of the duration of exposure of the samples. Cement composites are durable for longer periods and losses in strength due to weathering are offset by strength gains due to age-related hardening (carbonation) of cement [44]. According to Shirakawa et al. [24], bio-deterioration is not a major problem in fibre cement technology, since fungi and termite do not cause significant deterioration even after accelerated carbonation of composites.

The mechanical properties evaluated after the fungal exposure period revealed strength losses among all tested samples. This could be due to the terminal effect of fungi on the structural performance of the panels. The panels exposed to fungi were selected for the test, as the panels were resistant to termite damage. The MOE for control sample was $518 \mathrm{MPa}$ compared to $621 \mathrm{MPa}$ before exposure (Fig. 3). For samples with $8 \%$ fibre content, the MOE changed from 1298 to $966 \mathrm{MPa}$ after exposure. This represents a loss of about 16.6 and $25.6 \%$ for control samples and samples containing $8 \%$ fibre, respectively. In MOR, control samples decreased by $30.2 \%$ after exposure, while samples containing $8 \%$ fibre decreased by $34.3 \%$. IB in the control samples decreased by 
Fig. 3 Comparison of panel mechanical properties before and after exposure $(1=$ before exposure; 2 =after exposure; $0-10=$ fibre content)

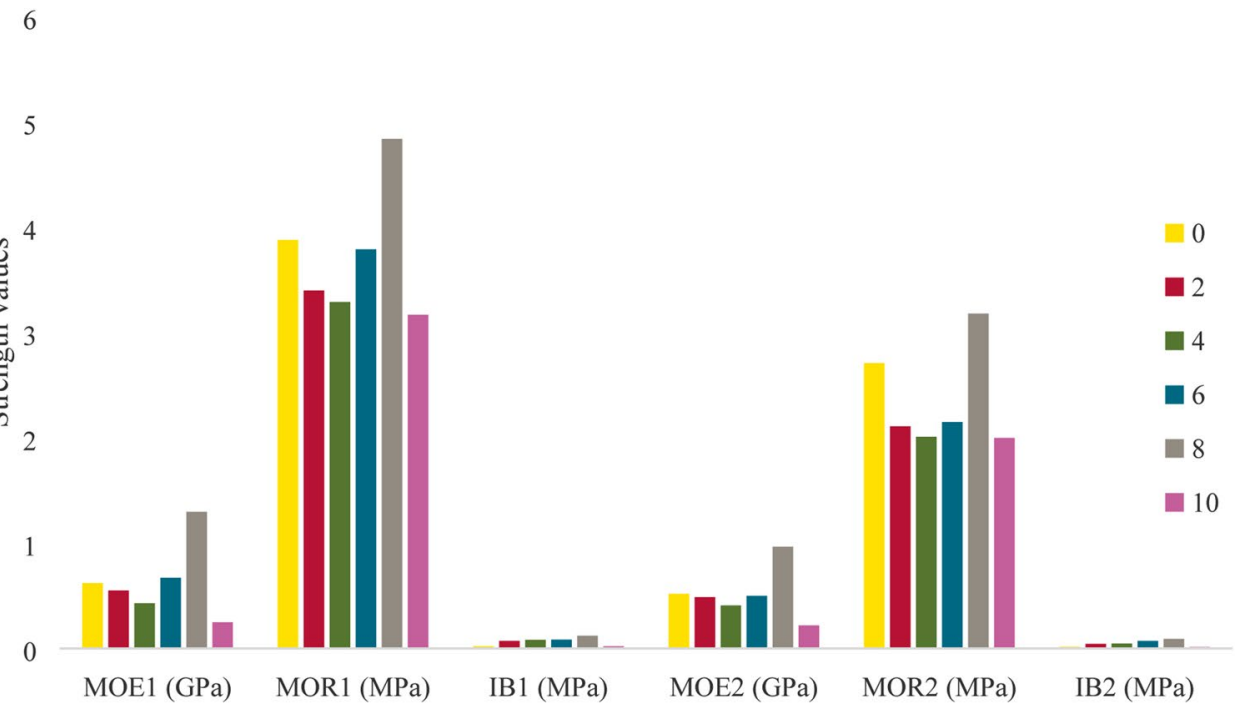

$28.6 \%$ after exposure, while samples containing $8 \%$ fibre decreased by $25 \%$. Fungi activity could have resulted in slow degradation of cell wall components, and an eventual loss in all strength properties. However, the strength loss was not significant $(p<0.05)$. The exposure already changed the physical characteristics of the materials, which were unstable with prolonged submersion in water.

\section{Conclusion}

The incorporation of kenaf bast fibres to reinforce wastepaper-cement composite boards has been discussed. The manufacture of these reinforced composite materials utilizing recycled waste papers will help to promote a circular bioeconomy and improve the economic potentials of developing countries. The manufacturing process is suited to the end of technology spectrum, as it presents opportunities for small-scale enterprises to produce durable and affordable fibre-cement materials. Apart from the proposed application of these materials as wall claddings in the research arboretum, they can be used as non-load-bearing structures as well as ceiling applications in residential dwellings.

From the result of this study, kenaf bast fibres can be used to improve the flexural strength and dimensional stability of waste paper-cement composites. The optimum fibre content for improving the measured properties evaluated was $8 \%$ for a paper: cement ratio of $1: 1(\mathrm{w} / \mathrm{w})$. This optimum content was determined as the maximum strength attained when fibres were added to the composites. At $8 \%$ fibre content, there is increased fibre-cement interaction, good fibre distribution within the matrix and good interfacial bonding in the composite materials. There was no correlation between the fibre content and the physical properties evaluated, but the effect of fibre content was significant on the WA and
LE. The composite panels were highly resistant to mould (fungi) attack and termite damage for an exposure period of 24 weeks. In addition, 12-week accelerated decay test using the brown and white-rot fungi did not result in any significant loss in weight of the samples. There was no visible mycelia growth or termite activities in the exposed specimens. Although, there was a decrease in mechanical properties after exposure, the strength loss was not significant. The high $\mathrm{pH}$ of the cement matrix and dissolved $\mathrm{CaCl}_{2}$ salt was concluded to improve the durability of the specimens. Based on these results, the composite materials can be successfully applied to manufacture wall panels for the arboretum buildings in the University of Benin.

Acknowledgements Open access funding provided by Linnaeus University. The authors wish to thank Dr O.N. Adeniyan of the Institute of Agricultural Research and Training (IAR\&T), Moor Plantation, Ibadan, for providing the kenaf bast fibres.

\section{Compliance with ethical standards}

Conflicts of interest The authors declare that they have no conflict of interest.

Open Access This article is licensed under a Creative Commons Attribution 4.0 International License, which permits use, sharing, adaptation, distribution and reproduction in any medium or format, as long as you give appropriate credit to the original author(s) and the source, provide a link to the Creative Commons licence, and indicate if changes were made. The images or other third party material in this article are included in the article's Creative Commons licence, unless indicated otherwise in a credit line to the material. If material is not included in the article's Creative Commons licence and your intended use is not permitted by statutory regulation or exceeds the permitted use, you will need to obtain permission directly from the copyright holder. To view a copy of this licence, visit http://creativecommons.org/licenses/by/4.0/. 


\section{References}

1. Achour A, Ghomari F, Belayachi N (2017) Properties of cementitious mortars reinforced with natural fibers. J Adhes Sci Technol 31(17):1938-1962

2. Amiandamhen SO, Izekor DN, Balogun AO (2016) Performance characteristics of treated kenaf bast fibre reinforced cement composite. J Indian Acad Wood Sci 13(2):156-160

3. Onuaguluchi O, Banthia N (2016) Plant-based natural fibre reinforced cement composites: a review. Cem Concr Compos 68:96108. https://linkinghub.elsevier.com/retrieve/pii/S095894651 6300269

4. Akinyemi BA, Bamidele A, Joel E (2019) Response of coir fibre reinforced cement composites to water repellent chemical additive and microwave accelerated curing. Cellulose. https:// link.springer.com/10.1007/s10570-019-02414-z

5. Yadollahi R, Hamzeh Y, Ashori A, Pourmousa S, Jafari M, Rashedi K (2013) Reuse of waste sludge from papermaking process in cement composites. Polym Eng Sci. https://onlinelibr ary.wiley.com/doi/pdf/10.1002/pen.23283

6. Cavdar AD, Yel H, Boran S, Pesman E (2017) Cement type composite panels manufactured using paper mill sludge as filler. Constr Build Mater 142:410-416

7. Shimada M, Iida T, Kawarada K, Chiba Y, Mamoto T, Okayama T (2000) Porous structure of activated carbon prepared from waste newspaper. J Mater Cycles Waste Manag 2(2):100-108

8. Kamimura A, Konno E, Yamamoto S, Watanabe T, Yamada K, Tomonaga F (2009) Formation of recycled plastics from depolymerized monomers derived from waste fiber-reinforced plastics. J Mater Cycles Waste Manag 11:38. https://doi. org/10.1007/s10163-008-0217-1

9. Kamimura A, Akinari Y, Watanabe T, Yamada K, Tomonaga F (2010) Efficient chemical recycling of waste fiber-reinforced plastics: use of reduced amounts of dimethylaminopyridine and activated charcoal for the purification of recovered monomer. $\mathbf{J}$ Mater Cycles Waste Manag 12(2):93-97

10. Amiandamhen S (2013) Technology and market opportunities in fiber cement composites for small scale enterprises in Nigeria. Glob J Agric Sci 12(1):11-14

11. Dhakal HN, MacMullen J, Zhang ZY (2016) Marine applications of advanced fibre-reinforced composites, pp 103-124. 10.1016/B978-1-78242-250-1.00005-3

12. Fan M, Fu F (2017) Introduction: a perspective-natural fibre composites in construction. In: Fan M, Fu F (eds) Advanced high strength natural fibre composites in construction. Elsevier, UK, pp 1-20

13. Moslemi AA (2008) Technology and market considerations for fiber cement composites. In: 11th international inorganicbonded fiber composites conference, Madrid, Spain, pp 13-29

14. Djafari PSR (2017) Physical and mechanical properties of natural fibers. In: Fan M, Fu F (eds) Advanced high strength natural fibre composites in construction. Elsevier, UK, pp 59-83

15. Karade SR, Irle M, Maher K (2003) Assessment of wood-cement compatibility: a new approach. Holzforschung 57:672-680

16. Fan M, Ndikontar MK, Zhou X, Ngamveng JN (2012) Cementbonded composites made from tropical woods: compatibility of wood and cement. Constr Build Mater 36:135-40. https://www. sciencedirect.com/science/article/pii/S0950061812002917

17. Na B, Wang Z, Wang H, Lu X (2014) Wood-cement compatibility review. Wood Res 59(5):813-826

18. Hachmi M, Guelzim M, Hakam A, Sesbou A (2017) Woodcement inhibition revisited and development of new woodcement inhibitory and compatibility indices based on twelve wood species. Holzforschung 71(12):991-998
19. Li X, Tabil LG, Panigrahi S (2007) Chemical treatments of natural fiber for use in natural fiber-reinforced composites: a review. J Polym Environ 15:25-33

20. Amiandamhen SO, Izekor DN (2013) Effect of wood particle geometry and pre-treatments on the strength and sorption properties of cement-bonded particle boards. J Appl Nat Sci 5(2):318-322

21. Okino EYA, De Souza MR, Santana MAE, Alves MVDS, De Sousa ME, Teixeira DE (2005) Physico-mechanical properties and decay resistance of Cupressus spp. cement-bonded particleboards. Cem Concr Compos 27(3):333-338

22. Garcia CM, Eusebio DA, San Pablo MR, Villena EM (2012) Resistance of wood wool cement board to the attack of Philippine termites. Insects 3(1):18-24

23. Priyadharshini S, Ramakrishna G (2017) Recent developments in durability of natural fibre cement/cementitious compositesa review. ARPN J Eng Appl Sci 12(23):6851-6868

24. Shirakawa MA, Aihara EY, Marcos C, Dias R, Gaylarde CC, John VM (2008) Fungal colonization on fiber cement exposed to the elements in a tropical climate. In: 11th International conference on durability of building materials and components, Istanbul Turkey, pp 1-8. https://www.irbnet.de/daten/iconda/ CIB13062.pdf

25. Ding D, Yu T, Li Y (2017) Effect of fungi on the properties of jute/poly (lactic acid) composites. In: 21 st International conference on composite materials, Xi' an, pp 1-8. https://www.iccmcentral.org/Proceedings/ICCM21 proceedings/papers/3176.pdf

26. Jessen M (2014) Effects of termites (Macrotermes) and large herbivores on exotic and native tree species in Lake Mburo National Park, Uganda. Dissertation, Norges miljø-og Biovitenskapelige Universitet. https://pdfs.semanticscholar.org/fce6/cd1daa68d0 ebef5cbc7f05806603d3ffc7fe.pdf

27. Azrieda NAR, Salmiah U, Rahim S (2015) Comparison of accelerated decay and graveyard test on selected Malaysian timber species. J Trop Resour Sustain Sci 3(2015):238-241

28. ASTM D1037 (2013) Standard test methods for evaluating properties of wood-base fiber and particle. Annual Book of ASTM Standards. West Conshohocken, PA. American Society for Testing and Materials

29. Biles CL, Wright D, Fuego M, Guinn A, Cluck T, Young J, Martin M, Biles J, Poudyal S (2012) Differential chlorate inhibition of Chaetomium globosum germination, hyphal growth, and perithecia synthesis. Mycopathologia 174(5-6):475-487

30. Traoré S, Tigabu M, Jouquet P, Ouédraogo SJ, Guinko S, Lepage M (2015) Long-term effects of Macrotermes termites, herbivores and annual early fire on woody undergrowth community in Sudanian woodland, Burkina Faso. Flora Morphol Distrib Funct Ecol Plants 211:40-50

31. Leuthold BRH, Triet H, Schildger B, Sa IH, Cell R (2004) Husbandry and breeding of African giant termites (Macrotermes jeanneli) at Berne Animal Park. Zool Garten 74(1):26-37

32. Mohr BJ, El-Ashkar NH, Kurtis KE (2004) Fiber-cement composites for housing construction: state-of-the-art review. Proc NSF Hous Res Agenda Workshop 17

33. Amuthakkannan P, Manikandan V, Jappes JTW, Uthayakumar M (2013) Effect of fibre length and fibre content on mechanical properties of short basalt fibre. Mater Phys Mech 16:107-117

34. Odera RS, Onukwuli OD, Osoka EC (2011) Optimization of the flexural strength of raffia palm fibre-cement composites. J Emerg Trends Eng Appl Sci 2(2):294-297

35. Coutts RSP (1987) Air-cured woodpulp, fibre/cement mortars. Composites 18(4):325-328 
36. Oladele IO, Akinwekomi AD, Aribo S, Aladenika AK (2009) Development of fibre reinforced cementitious composite for ceiling application. J Miner Mater Charact Eng 8(8):583-590

37. Thirmizir AMZ, Ishak MZA, Taib MR, Sudin R, Leong YW (2011) Mechanical, water absorption and dimensional stability studies of kenaf bast fibre-filled poly (butylene succinate) composites. Polym Plast Technol Eng 50(4):339-348

38. BS EN 634-2 (2007) Cement-bonded particleboards-Specifications-Part 2: Requirements for OPC bonded particleboards for use in dry, humid and external conditions. British Standand

39. ASTM D2017 (2005) Standard test method for accelerated laboratory test of natural decay resistance of woods. Annual Book of ASTM Standards. Vol. 04.09. Philadelphia. American Society for Testing and Materials

40. BS EN 350-1 (1994) Durability of wood and wood-based products-natural durability of solid wood-Part 1: guide to the principles of testing and classification of the natural durability of wood. vol. 3, Brussels, British Standard

41. Sukartana P, Rushelia R, Sulastiningsih IM (2002) Resistance of wood- and bamboo-cement boards to subterranean termite
Coptotermes gestroi Wasmann (Isoptera: Rhinotermitidae). In: Evans PD (ed) Wood-cement composites in the Asia-Pacific Region, Canberra: ACIAR, pp 62-65. https://invenio.unidep.org/ invenio//record/10104/files/pr107_pdf_13752.pdf

42. Roszaini K, Salmiah U, Rahim S, Shahlinney L, Azried NAR, Baharudin K, Adawi MTO, Kum PS, Hamidah A (2017) Qualitative and quantitative determination of resistance of twenty two Malaysian commercial timbers through subterranean termite feeding behavior. For Res Eng Int J 1(2):52-60

43. Winandy JE, Morrell JJ (2017) Improving the utility, performance, and durability of wood- and bio-based composites. Ann For Sci 74(25):1-11

44. Dinwoodie JM, Paxton BH (1989) A technical assessment of cement-bonded particleboard. In: Moslemi AA (ed) Fiber particleboards bonded with inorganic binders, pp 115-122

Publisher's Note Springer Nature remains neutral with regard to jurisdictional claims in published maps and institutional affiliations. 